\title{
Privatisation of Non-Profit Organisations*
}

\author{
Veljko Rus**
}

This paper deals with the transfer of property rights from non-private to private agencies. First macro- as well as micro-contingencies of privatisations are shown. Then measures are described which should be applied before privatisation of a public services can start. After showing some of the dysfunctions of privatization in Eastern European countries the article closes with contingencies for cooperative polyarchies and the presenting of the variety of problems related to privatisation in non economic, especially schools, hospitals, theatres and prisons. The expected outcome of the above suggestions is the "third way" after Anthony Giddens: "The new mixed economy looks for a synergy between public and private sector utilizing the dynamism of markets but with the public interest in mind" (Giddens, 1998:99-100).

In diesem Aufsatz geht es um den Transfer von Eigentumsrechten von nichtprivaten auf private Vertreter. Zunächst werden Kontingenzen im Makro- und im Mikrobereich beleuchtet. Danach werden Maßnahmen beschrieben, die getroffen werden sollten, bevor die Privatisierung eines öffentlichen Dienstes beginnen kann. Nachdem einige Fehlleistungen bei Privatisierungsprozessen in Osteuropäischen Ländern aufgezeigt werden, werden zum Abschluß die Kontingenzen für kooperative Polyarchien und eine Vielzahl von Problemen bei der Privatisierung im nicht-ökonomischen Bereich dargestellt. Dabei geht es insbesondere um Schulen, Krankenhäuser, Theater und Gefängnisse. Als Ergebnis wird der "dritte Weg", nach Anthony Giddens, festgestellt: "Die neue 'mixed economy' versucht, einen Synergieeffekt zwischen öffentlichem und privatem Sektor zu erzielen und so die Dynamik von Märkten mit dem öffentlichen Interesse als Hintergrund nutzbar zu machen." (Giddens, 1998:99100)

\footnotetext{
* Manuscript received: 02.06.97, revised: 30.11.98, accepted:18.12.98.

** Veljko Rus (*1929), Faculty of Social Sciences, Center for Strategic and Policy Evaluation Studies, Ljubljana; main research topics: Power and Responsibility in Enterprises, Quality of Life, Welfare State and Privatization of Social Services.
} 


\section{Introduction}

In this paper privatisation is treated as a transfer of property rights from nonprivate to private agencies. Property rights are usually classified as ius disponendi, ius (ab)utendi and ius fruendi. In managerial literature these rights are usually rendered into more operative terms such as:

- decisions about constitutive issues, e.g. buying and selling assets; establishing and winding up organisations; establishing and changing leadership and the rules of management; these constitutive decisions correspond to ius disponendi;

- decisions about management policy, optimisation of resource utilisation, risk taking, policy preferences; these correspond to ius (ab)utendi;

- decisions about allocation of profit and distribution of personal incomes, as well as allocation of other bonuses; these decisions correspond to ius fruendi.

As we can see from the above classification of property rights and correspondent decisions, privatisation refers not only to physical and financial resources, but also to non-material resources which pertain to activities of stakeholders. These are even more salient for privatisation of social services than financial and physical, since they create so-called "good" or "bad" will.

In this paper, under non-material capital resources we include intellectual and social capital; the first contains the knowledge, experiences and creativity of the employees, and the second both the weak and strong ties among employees (Burt, 1992). As we will see later, non-material capital resources are usually ignored in the processes of privatisation, although they are perhaps the most strategic component of them.

\section{Macro-Contingencies of Privatisation}

The undesired outcomes of privatisation are in most cases caused by local contingencies. The differing outcomes of the same forms of privatisation draw us to a new hypothesis whereby we might expect that outcomes of privatisation should be effected by both: a. environmental structures and b. by selected forms of privatisation.

When we observe the predominantly negative economic, political and social effects of privatisation, we usually neglect the fact that processes of privatisation in Europe are not influenced by Thatcherism alone, but more by "Pinochetism". This point is elaborated by Whitefield (1993), who has demonstrated how Chile became a main prototype of contemporary privatisation processes. Privatisation in Chile started immediately after the fall of Allende's regime, which means earlier than in the U.K. Owing to the domination of ideological goals and external political forces, privatisation in Chile was from the very beginning condemned to economically negative results: more than $70 \%$ of denationalised 
firms in the first three stages of privatisation went bankrupt or have been sold to new owners.

The domination of ideological goals in Chile's privatisation is documented by four models of societies: Capitalismo Popular, Capitalismo Laboral, Capitalismo Institucional and Capitalismo Tradicional. As we see, all forms of privatisation have been oriented towards restitution of capitalist society and not towards some country-specific arrangements which might have surpassed the failures of both: socialism and capitalism.

The Chilean model later came to dominate the British, Third World and Eastern European privatisation policies. In common with the Chilean privatisation process is the domination of external forces in Third world and Eastern European countries, such as the World Bank, IMF, OECD, EU, GATT and certain other financial institutions. They have made loans to Third World countries conditional on several factors including privatisation programmes. The World Bank had already imposed privatisation programmes on 83 countries of the developing world by 1986 .

This so-called "new imperialism" (Whitefield, ,1993; 285) was also implemented later in the Eastern European countries, and has the same dysfunctions as decades earlier in the Third World. The main reason for the negative economic and social effects of privatisation has been the withdrawal of the state from the economy at a time when the local market, the local bourgeoisie and management were not sufficiently developed. Because of such contingencies, a lack of social regulation and a degree of chaos have been the unavoidable consequences of deregulation and privatisation in the Third World and Eastern Europe.

\section{Micro-Contingencies of Privatisation}

In the preceding chapter mentioned hypothesis that the outcomes of privatisation are perhaps on the macro level more dependent on power relations than on forms and methods of privatisation becomes even more obvious when we observe privatisation processes at the organisational level.

The best illustration of this hypothesis are employee shares and/or ESOPs programmes introduced by the British and American governments. At the very beginning it was expected that employee shareholding would successfully substitute for workers' control and industrial democracy. In reality the opposite has happened: introduction of employee share ownership has increased the control of managers and reduced the control of workers and unions. There are a number of reasons for this unexpected outcome, including the followings:

a) employee shares usually represent only a tiny proportion of companies' shares (in most companies employees hold less than $1 \%$ of all shares while in 
those that have introduced ESOPs, employees' shares do not exceed 5\% of the total);

b) introduction of employee share ownership does not change the existing managerial structure within companies, which means that management control is structurally ensured through its unchanged status and role;

c) employee share ownership creates double identification of employees; they perceive themselves as workers and at the same time as shareholders; as shareholders they are less committed to the unions and more disposed towards the firing of their co-workers;

d) the nature of share ownership itself increases mutual dependence; while the ownership of goods or land represent full property rights, which allows full power over the property, share ownership means dependence on the other shareholders; in a case when managers are most powerful group, interdependence is transformed into the asymmetrical dependence of workers from managers.

Theoretically the last contingency is perhaps the most decisive, since it tells us that a greater proportion of employee shares should not automatically lead to greater democratisation of organisations (i.e. greater power equalisation between workers and managers).

On the other hand we could also expect numerous desirable effects of employee share ownership on management. Through employee share ownership the management might:

- increase saving and investment sources within companies

- increase organisational resistance to hostile take-over

- increase resistance of the organisation to recession and stagflation

- reduce conflicts and increase co-operation with employees.

Russell (1985) believes that the last preference is relevant for management itself. In his view, management shares are less important as a source of management power, and more relevant as a motivational factor and as a source of their identification with the company.

\section{From Resistance to Alternative Coalitions}

While resistance to privatisation is almost non-existent in Eastern European countries, with the exception of Poland's Solidarity, it is quite strong among Western European unions. However stronger resistance of the unions to privatisation might be expected if they will be able to accomplish:

- greater international integration of national unions

- stronger union organisation at the level of the workplace 
- tactical use of industrial action and negotiating mechanisms.

All the above measures may be focused only to one goal: to increase the unions' counterbalance of power against the privatisation of the public sector. Such an orientation reminds us of England at the beginning of the 19th century, when the Chartist movement of unions tried to stop the industrialisation of the country. It reminds us not only because of its utopian action but also because of its conservativism.

Alternative to this traditional antagonism between capital and labour is employee shareholding system and greater integration of employees not only into production processes but also into management policy and entrepreneurial risk.

In the field of social services more promising movement and less conservative resistance might be generated by a coalition of producers and users. For the creation of such a coalition it would be necessary to:

- define the unsatisfied needs of people and create corresponding demands;

- educate and mobilise actual and potential users;

- establish joint committees of producers and users;

- organise constant pressure of joint producers and users on government;

- improve the supportive role of government.

If such a coalition were established, it might reorient the privatisation of public sector from predominantly profit-based activities towards need-satisfying activities. The implications of such a reorientation could be decommercialisation and resocialisation of the public sector. In this case most organisations within the public sector should be transformed into non-for-profit organisations; these have a status which is more compatible with such a reorientation.

For those who believe that privatisation is nothing other than the "greatest ever public fraud" (Whitefield, 1993; 170), the best alternative to privatisation is revitalisation of the public sector itself. By fraud, these critiques mean indirect and invisible costs of privatisation which are supposedly much greater than those registered and announced publicly. According to some calculations, the costs of privatisation consume two thirds of sale value. Taking into account that the savings achieved through privatisation are not 20 to $30 \%$ but in reality 6 to $7 \%$, one could see privatisation as an economically entirely unproductive measure.

For such critics the logical alternative to privatisation is revitalisation of the public sector. Revitalisation is for them a complex project and should be achieved through:

1. more sophisticated analyses of social needs and better response on these needs 
2. more systematic evaluation of goods and services from the following aspects: a) quality of services, b) effectiveness, c) efficiency and d) equity

3. internal reorganisation which should create a more flat and less hierarchical structure of organisations, more decentralised decision-making and greater involvement of unions in management

4. improvement of management, especially by improving service delivery

5. development of industrial democracy which should be realised through greater participation of employees, improvement of grievance procedures and a better developed bargaining system

6. creation of branch and sectoral social contracts

7. greater and more direct responsibility of management to political bodies, to their own employees and users

8. improved equity, i.e. more equal access to goods and services and creation of equal opportunities for all citizens

9. more transparent finances

10.better HRM, i.e. better training and promotion of employees

Those experts who are influenced by the ideas of postmodernism suggest more eclectic solutions. They agree that various forms of privatisation should be applied, but not at the same time. According to Samson \& Colin (1994) contracting out services or just particular functions should precede the sale of state assets. According to Whitefield (1993), after these two steps, deregulation and commercialisation should follow.

My personal view is that numerous measures should be applied before privatisation of a public services can start. The sequence of measures which should be implemented before privatisation starts should be as follows:

1. revitalisation of public organisations as suggested above

2. deregulation, wherein the main goal is to surpass the monopoly of the public over the private sector

3. professionalisation, which should increase the autonomy of professionals inside public organisations through self-organisation and power of veto over all decisions which are incongruous with expertise

4. socialisation through involvement of users or clients in external (vouchers) and internal (co-opting into management control bodies) regulation

5. commercialisation of the public sector, through establishment of contractual relations between state and public organisations

The above measures would provide all the necessary conditions for fruitful competition, which should improve the effectiveness and efficiency of public 
organisations. Truly responsible privatisation could therefore be started only after and not before these measures.

\section{Dysfunctions of Privatisation in Eastern European Countries}

The ideological orientation towards restitution of capitalism, as the main cause of dysfunctional privatisation, is prevailing phenomenon also in Eastern and Central European countries (ECEC). According to Becker (1993) the outcome of such an ideologically and politically contaminated privatisation is a form of cryptocapitalism which leads towards a latinamericanisation of these societies. Many experts from these countries have made similar observations. For instance, Zajiček (1993) describes predominantly negative results of privatisation in Poland (such as unemployment, inflation, economic stagnation and reduction in the quality of life). He believes the causes of these negative results of privatisation are primarily:

- excessively rapid privatisation, which has expanded without a solid legal framework

- inequitable distribution of the consequences of privatisation across the social classes

- lack of competition to promote economic efficiency.

Very similar causes of unsuccessful privatisation are also mentioned by McIntosh (1994). He believes that the main obstacles to privatisation in the ECEC are:

- lack of free market culture

- confusion over ownership arrangements at the company level

- absence of legal structure regulating business activities and

- inadequate infrastructure which has discouraged foreign investment.

The consequences of these circumstances are higher prices for basic goods and services, large scale layoffs, loss of national assets to foreign buyers and closure of some vital industries.

If we tried to summarise the above observations, we might say that privatisation in the ECEC might lead these countries from the Second to the Third World. If this were to become reality, there is little doubt that we would not be able to avoid dilemma formulated by Machonin (1994): further continuation of liberal democratic reforms or populist/authoritarian interruption?

More recently we might have observed some reorientation from "shock therapy" towards more gradual and sequential strategies of privatisation. It is important, for instance, that in the Czech Republic and the former East Germany, small privatisation was first introduced, while privatisation of medium and large 
enterprises followed. It is also encouraging that Hungary has developed some kind of sequence of different types of privatisation, such as the so-called preprivatisation, self-privatisation and distributive privatisation. Non less is relevant the case of Slovenia where shock therapy has been refused at the very beginning. It is widely recognised that privatisation in this country has been least harmful, just because Jeffery Sacks plan was not accepted (Whitely, 1997).

In theories, different forms of privatisation are rather more evolved, and their social consequences are becoming more visible. Cox (1994) for instance has tried to cope different forms of privatisation with specific social strata. According to his classification:

1. spontaneous privatisation is promoted chiefly by the old economic elite and partly by the nomenklatura

2. state regulated forms of privatisation are promoted chiefly by the new governing elite

3. privatisation through sale of shares or entire companies is forced by foreign capital

4. re-privatisation of business and land is promoted mainly by former owners

5. state facilitation of small \& medium enterprises is stressed by the new economic elite which originates in the former second or grey economy

6. employee share ownership is imposed by employees and unions

7. the general distribution of shares to citizens is promoted by both the new and old political elite.

It would appear that the above connections between social actors and forms of privatisations are applicable more or less to all the ECEC. If this is the case, then there must be some latent structure of relations which means that we may expect less chaotic and more conflicting developments in the privatisation of social services in these countries.

In spite of these improvements, however, short-term goals still prevail over long-term ones (Oppen, 1994). As part of the long-term goals, competition and co-operation between the private and public sector should be enhanced with the aim of increasing economic growth and economic democracy. Instead of such a long-term orientation, the short-term orientation towards economic efficiency and political stability prevail, forcing the reintroduction of authoritarian management and abandoning of welfare programmes.

After ten years of experimentation it becomes clear that the transition conceived as a change from domination of labour over capital into a society in which capital will again dominate over labour is not only morally unacceptable and socially damaging but also a historically obsolete regression. This "return to capitalism" of ECEC countries is forced in time when the most competent 
experts are describing western countries as post-capitalistic social arrangements! (Drucker, 1992)

The main orientation of societies in transition therefore cannot be reinstatement of capitalism but some kind of post-socialist and post-capitalist society (Rus, 1992) in which a kind of equilibrium between labour and capital would be established. Whether this equilibrium will be achieved through conflict, cooperation, or integration is another question, and will be dealt with later.

\section{Coalition Formation Through Privatisation}

The welfare state is treated here as a more or less integrated system of social services (schools, hospitals, kindergartens, old people's homes etc). Through it the nature and the function of the state has been thoroughly changed. While the ancien regime exercised its integrative role through oppressive hierarchically organised entities such as the army, police and prisons, the welfare state exercises its social integration through non-coercive methods whereby qualitative reproduction of the whole population can be assured.

As Foucault (1977) would say: the welfare state allows the transition of a state from:

- political power to "biopower"

- centralised macro-regulation to capillary micro-regulation

- political economy to political anatomy

- property system of power to management system of decision-making

- external coercive power to internal control of mind.

Social services therefore do not offer only "satisfactions" (activities by which certain needs are met), but they also offer non-coercive forms of social integration through the qualitative reproduction of populations.

The crisis in the welfare state, which became more visible after the first oil shock, was treated primarily as a financial crisis. And as a remedy, cost cutting and cost saving achieved through privatisation of social services was suggested. Was this an appropriate response to the crisis, especially if we take into account the various functions of social services in contemporary societies? And was the crisis of the welfare state only a financial crisis?

Taking account of different approaches, experts may interpret this crisis in the following way:

- economists treat the welfare state as the main obstacle to economic growth

- political scientists treat the welfare state as an invasion of the state into civil society 
- sociologists see the welfare state as an instrument of integration and homogenisation of the middle classes and at the same time as an instrument of marginalisation of the lowest classes

- psychologists see the welfare state as the main factor in increasing helplessness and dependence of citizens on the state

- moralists see in the welfare state a substitute for interpersonal and intergroup solidarity, where the result is the lack of moral responsibility at the level of interpersonal relations.

If we start to think of privatisation as a remedy for the welfare state, we should be aware of the complexity of this crisis. Although privatisation could not solve every problem, it should be implemented in such a way that it will not create disequilibrium between political, economic and social goals. It should therefore not result in the domination of owners and managers in social services, since this would force clear domination of economic goals over social and political ones. On the other hand, privatisation should also surpass the traditional domination of political goals in ECEC.

To assure the above equilibrium, at the level of macro-regulation we should take into account at least combinations of economic and political contingencies. From this point of view the following table of Adrian Charles (1985) might be of some interest:

Table 1: Power distribution as the outcome of political and economic contingencies:

\begin{tabular}{|l|l|l|}
\hline \multicolumn{1}{|c|}{$\begin{array}{l}\text { Political } \\
\text { system } \\
\text { Economic }\end{array}$} & Centralised & Decentralised \\
\hline Public ownership & $\begin{array}{l}\text { 1. } \\
\text { Bureaucratic } \\
\text { centralism } \\
\text { (politicisation) }\end{array}$ & $\begin{array}{l}2 . \\
\text { Domination of experts } \\
\text { (professionalisation) }\end{array}$ \\
\hline Private ownership & $\begin{array}{l}\text { 3. } \\
\text { Domination of clients } \\
\text { (socialisation) }\end{array}$ & $\begin{array}{l}\text { 4. } \\
\text { Domination of mgmt } \\
\text { (commercialisation) }\end{array}$ \\
\hline
\end{tabular}

Privatisation in most Eastern as well as Western countries is moving mainly from square one to square four, while the other two squares are usually ignored. Many experts have been warning that such an orientation of privatisation could generate extremely undesirable outcomes, because they totally marginalise experts and clients as equally important "stakeholders". Without these two groups of stakeholders we could not expect sufficient professionalisation and socialisation of privatised social services such as schools and hospitals. If these 
two groups are marginalised we should expect excessive commercialisation of private services on the other hand.

Much worse results might be expected in a case that through such a privatisation, a coalition of management and politicians were to be established. If such a coalition were established one might expect serious deprofessionalisation and desocialisation of social services. To prevent this some experts are already stressing the need to increase public or state control parallel to privatisation (Bensusan, 1993, O'Looney, 1993). If these suggestions are taken into account, privatisation might move somewhere to between squares 3 and 4. Such a solution is certainly not optimal but it is a much better alternative than the coalition between politicians and professionals which have been established recently in Eastern countries.

A coalition between experts and clients could be more acceptable than previously mentioned coalitions, although its appearance is less probable. However, such a coalition has been already mentioned by Whitefield (1993; 368 ) as a condition for revitalisation of public services. He believes that through active participation of professionals and clients, social services might be more oriented towards satisfaction of need than towards profit-making activities. Marketisation might in such circumstances have a benign role: it could stimulate cost saving activities of employees and entrepreneurial behaviour of management. Such an ideal solution tacitly presupposes co-operative relations between all four groups: politicians, professionals, clients and managers (and/or owners), where professionals and clients would play a dominant role, and the other two groups a supportive role.

\section{Contingencies for Co-operative Polyarchies}

Although we might observe long-term trends of increasingly "fuzzy boundaries" (Sasoon, 1998) between public and private sectors, traditional antagonisms between these two still are pretty strong. As a consequence also relations among above mentioned four groups are more frequently antagonistic than cooperative. Therefore spontaneous creation of coalitions between all four groups could not be expected. It is our task to look for such regulative arrangements which might support a kind of co-operative equilibrium between the above four "stakeholders".

The first condition for such a co-operative coalition is more or less even distribution of power, which might be achieved through polyarchic distribution. While such a polyarchy is necessary, it is not yet a sufficient condition for their co-operation. It is therefore our task to create all external and internal contingencies which would facilitate a co-operative polyarchy among the above-mentioned four stakeholders. Among the external contingencies the following are relevant: 
1. Desegregation of property rights: ius disponendi, ius utendi, and ius fruendi should not be allocated only to one of four stakeholders. Ius disponendi, which is implemented through the constitutive decisions should be in the hands of governmental bodies (politicians) and users (or clients), while ius utendi and fruendi should be shared among management, professionals and other employees. It is of course critical how decisions about constitutive issues would be shared between government bodies and users, but for this paper it is enough to stress that desegregation of property rights is a necessary condition for power sharing among all four stakeholders.

2. Hybrid forms of privatisation are more compatible with co-operative polyarchy than hidden and full privatisation forms (Savas, 1982).

Table 2: Forms of privatisation

\begin{tabular}{|l|l|l|}
\hline Hidden & Hybrid & Full \\
\hline Contractual plans & Concessions & Leasing \\
\hline Mgmt contract & Franchising & Sale of shares \\
\hline Public corporations & Vouchers & ESOPS \\
\hline
\end{tabular}

Hidden forms of privatisation allocate the whole power to government bodies and management and prevent power sharing of professionals and users. Full privatisation gives most power to internal groups, whether they are managers, professionals or employees and eliminate external groups like government bodies and users. More even power sharing might be achieved through forms of hybrid privatisation although through these forms of privatisation external groups might have a better status than internal. This is especially true in the case of vouchers. In the case of contracting out, however, top management and government bodies should have a better status than the other two groups.

Much depends on specific arrangements within specific forms of privatisation: shares for instance might be allocated evenly to all four groups or concentrated in the hands of one. Preference shares might also be in the hands of employees, while ordinary shares are in the hands of top management, banks and government bodies.

3. The non-for-profit status of social services is according to its own nature amphibious and therefore implies combined regulation through the market and through the state. The "profit test" (Drucker, 1986;177) is not only important for evaluation of efficiency of social services, but also and primarily because it reduces the propensity of management towards excessive growth. Managers in public services usually compensate the absence of a profit test by quantitative 
growth of their organisations, since growth becomes the only proof of their success.

The third criterion of effectiveness is more risk taking behaviour of management and more innovative policy by which it is possible to improve the quality of management in social services. On the other hand, non-profit status means that profit should be allocated only for more effective satisfaction of those human needs for which a particular service is designed. In this way the kind of equilibrium between the profit seeking and needs satisfying orientation of organisations is to some extent assured.

Double criteria of evaluation of non-for-profit organisation allows therefore more equal participation of all four groups: management and professionals who are interested in maximising quality of services and minimising their costs on the one hand and government bodies and users who are trying to promote an equal approach and responsiveness of services to the needs of clients on the other. Finally it must be stressed that such a non-for-profit status might be equally suitable to private, public and mixed social services which further facilitates a homogeneous and integrated system at the national level.

4. The fourth condition for creation of co-operative poliarchy is public competition. System of public competition (Casten von Otten, 1988) might be developed through introduction of vouchers, franchising, concessions etc. The system of public competition creates a kind of semi-economic and semi-political market and is compatible with the non-for-profit status of social services. It is different from the economic market, since allocation of (mainly public) financial resources is based on public tenders and not on the free market; but it is also different from the political market (Jorgessen, 1988) which is regulated by "distributive coalitions" representing the "public interest". It also differs from the political administrative market because the quality of services and efficiency of management are at least as relevant for allocation of financial resources as the already mentioned public voice of distributive coalitions. Jorgessen calls it a "market of public goods".

5. Neo-corporativistic regulation of state is a fifth condition for establishment of co-operative polyarchy. Neo-corporativistic regulation is not direct as in bureaucratic systems, where regulation is imposed by authoritatively imposed norms, nor is it a market type of indirect regulation where the state is trying through modification of market mechanisms to facilitate or hinder activities of organisations. Neo-corporativist relations are based on bargaining between government bodies and social service and are therefore partnership-like contractual relationships. In relation to the traditional corporativistic arrangements, where enterprises, associations or corporations have been used as an instrument of state control over civil society, the contemporary neocorporativistic arrangements are used primarily as channels through which the unions, professional associations and corporations are attempting to use the state 
as an instrument for promotion of their particular interests through public bodies and with the support of public finances (Cawson, 1985). It is therefore sometimes impossible to discern what is public and what is private, what should be public interest and what private and also what are government bodies for and what are private agencies for (Grant, 1985). It is however important to stress that in all cases partnership relations in principle do not exclude any of the abovementioned four stakeholders.

In addition to external contingencies, internal ones are also relevant for generation and maintenance of polyarchic co-operative coalitions among the four constitutive stakeholders. Since these issues are much better elaborated in literature, we will not go into detail here. Instead, we wish to stress the similarity between social service organisations and small labour-intensive enterprises in which internal active ownership (Rus, 1992) is not only the most acceptable but also the most feasible goal of privatisation. We should also stress that in service organisations, intellectual and social capital is not only quantitatively and strategically more important than financial and physical capital, but that there is also more intensive interdependence between all of them. This interdependence between all four capital resources allows not only polyarchy but also cooperative relations between partners. The structural design which supports such a co-operative polyarchy should be private and public, competitive and cooperative and a more loosely coupled than tightly integrated whole (O'Looney, 1993).

Finally it is also difficult to imagine a co-operative polyarchic coalition in service organisations without Japanese-style lifelong employment and without their HRM system, which has usually been called the $Z$ system (Ouchi, 1982). The recently discovered widespread system of ESOP in Japanese companies (Jones and Kato, 1993) confirm such a hypothesis. It is obvious that lifelong employment motivates employees to become shareholders in their own companies and at the same time stimulates higher commitment of employees to the enterprise and more co-operative relations towards the management.

\section{Privatisation of Schools, Hospitals, Theatres and Prisons}

With the intention of presenting the variety of problems related to privatisation in non economic organisations, we present here the privatisation of schools and hospitals but also prisons and theatres, although they are not part of the welfare state system.

\section{Schools}

For this sector of privatisations the following three specific problems seems to be mentioned: 
1. Limits of privatisation in this sector are much less numerous and strong than in the other fields of social services. Education does not have:

a) the character of a natural monopoly;

b) it is not dependent on economy of scale; and

c) it is not disturbed by the problems of "free riders".

Education was until the beginning of the 19th century treated as a private, not as a public good and also teaching was privately organised. During last two centuries, however, education was increasingly treated as a public good. The heavy polemics which are now accompanying the privatisation of schools have their origin mainly in these two conceptual evaluations of education as a public or private good. More recent orientations which try to treat education as a private and public good as well do not contribute very much to the convergence of the above positions. On the other hand, this orientation creates the future basis for a more flexible policy of privatisation of schools.

2. The great majority of educational privatisation plans prefer concessions (contracting out) and vouchers as a form of privatisation. We may say that they prefer hybrid forms of privatisation and not hidden or full forms. Very frequent proposals to introduce the voucher as a mean with which the educational free market should be established are perhaps to some extent motivated by the similar proposal of Milton and Rose Friedman (1980). Of course the main conflict is related to the further question: to whom these educational costs per capita should be delivered: to the teachers or to the parents?

3. It seems that the educational field is unique also concerning the relationship between privatisation and socialisation: the main goal of privatisation in this sector is not marketisation but socialisation of educational services. There are some authors - like Savas (1982) - who still believe that competition on the free educational market would cut the costs and improve the quality of education. Some other authors stress that through privatisation schools will become more responsive to the changes in the labour market and more open to the participation of parents in the management of schools (Daijiro, 1993). More mature theories of privatisation also stress that privatisation does not mean elimination of state or public control: this one should remain strong or become even stronger, but at the same time its quality and function should be substantially changed (Mowbray, 1993).

On the same line the actual situation in Denmark is of some interest. In this country the state provides all private and public schools with the same fee per pupil, imposes the same minimal standards for quality of services, and delegates control over teachers' activity to parents. 
Surprisingly enough, there are some distinguished professionals such as the president of the American Teacher Association - A. Shanker - who oppose any kind of privatisation of schools. He believes that privatisation could not solve any urgent educational problem in the USA, but would create dissolution of the national educational system by the concentration of $25 \%$ of the best pupils in elite schools and by the creation of educational ghettos for the other $75 \%$ of pupils.

Such a warning is perhaps more relevant for elementary schools which are conceived as non-selective educational organisations. However at the level of universities privatisation is perhaps much more desirable just because of the opposite reason. It is therefore not surprising if Arronowitz, (1998) see in privatisation of universities one of the key issue of American society.

\section{Hospitals}

Domination of private medicine in the USA and intensive privatisation of it in Britain have - according to many reports - many more negative than positive results. In the USA the main problems are contracts between government bodies and private hospitals, since more than $40 \%$ of all costs of private medicine are covered by public financial resources. While it is not difficult to define the amount of services and costs related to material inputs, it is almost impossible to specify the quality of services and their non-material inputs. Bovbjerg, Held and Pauly (1987) report that public competition, developed more recently, has not contributed to lower costs of services. The same has happened with vouchers. The explanation of inefficiency and ineffectiveness is similar: insurance agencies are unable to specify precisely enough the non-material costs, standards of quality for services, and rights of clients to certain services.

However, the absence of expected desirable results of quasi privatisation does not also mean the absence of undesirable outcomes. Relman (1993) reports that professionalism is giving way to entrepreneurialism. The priority to serve the needs of the sick is increasingly questioned by the economic orientation of doctors, who are losing their professional independence.

In Britain the privatisation of medicine, forced by Margaret Thatcher, has also more undesirable than desirable results (Ascher, 1989; Cooc, 1988; King, 1987). These authors report that privatisation of medicine in Britain resulted in:

a) lower quality of services

b) less equal access of citizens to services and

c) increased interventionism of government bodies.

Some analysts believe that these negative outcomes of privatisation are induced by the domination of ideological goals over pragmatic goals. We would like to suggest another hypothetical explanation: models of hybrid privatisation are not 
suitable for medicine since contractual relations could not be specified precisely enough. Therefore hidden forms of privatisation should be more frequently applied for hospitals and full forms of privatisation for primary medical activity.

More radical are the suggestions of Higgins and Rosental/1993/ who compare the more recent changes in Britain and Sweden. In Sweden, instead of privatisation, decentralisation of medical services has been introduced. It is reported that decentralisation has quite obvious desirable results since it:

a) increases the role of primary medicine, whose services are less expensive than hospitalisation

b) encourages development of privatisation in the field of the primary sector (which of course remains publicly controlled) and

c) makes easier specifications of cost for this sector and therefore more efficient contractual relations between public bodies and private doctors.

Different although not less radical are suggestions of Lily Hoffman (1998) who believes that increased costs as a result of privatisation of health organisations in Czeck Republic are unavoidable consequence until experts will keep dominating control over production of services.

\section{Prisons}

Privatisation of prisons is certainly the most intriguing topic within the framework of privatisation studies. The basic question here is whether any kind of contracting out is legitimate when public services are a part of the coercive system of state. Is not any coercion the exclusive monopoly of the state? If it is, no kind of privatisation is legitimate. If it is not, how far might we go with privatisations? Is the privatisation of the police and army also legitimate? And is there any limit for privatisation at all? This is the main topic of Sparks' article (1994). He believes that the contemporary debate about penal policy should be closely connected with the crisis of legitimacy. He believes that from the point of view of legitimacy, privatisation of prisons evades and suppresses more problems than it solves.

For those who are not involved with the legal grounds of privatisation of prisons, the main problem is technical and refers to the need for more detailed outlines of contracts with the management that will take over custodial services (Moyle, 1993). Such a technical approach prevails with other authors. McDonald (1994) believes that contracts with private managers who are taking over management of prisons should contain only pragmatic issues such as:

a) propriety of contracts

b) the monetary saving

c) the quality of services and 
d) the commitment to prisoners rights.

The suggestions of Ryan (1993) are similar. He also thinks that contracts between government bodies and management should be focused on cost of services and their quality measured by degree of public security and quality of life of prisoners.

As we can see from the above contributions, the question of the limits of privatisation and of the legitimacy of privatisation of prisons remain answered. And if we try to contribute some possible answers to the above questions we would like to suggest not talking about limits of privatisation but about the forms, methods and content of it. Concerning the privatisation of prisons, we suppose as appropriate forms only the so-called hidden forms of privatisation, since all the other (hybrid and full) raise too many questions about legitimacy.

\section{Theatres}

Although it is doubtful whether cultural services are a public or private good it is of some interest to see how privatisation in this field is progressing. Theatres are one of the most expensive cultural activities and therefore most relevant for privatisation, which should substantially decrease the public budget for their activities. We do not have reports on privatisation of theatres in the other ECEC, although there are some rumours that in most ECEC, financial arrangements between government bodies and theatres have been cancelled. Therefore we are able to report only on actual and future changes in Slovenia.

Slovenia has over the last 50 years been somewhere in between Europe and the USA. So-called repertory theatres have as in most European countries been state institutions. They have regular annual budgets with which they cover more than $90 \%$ of all costs. On the other hand so-called ad hoc, pocket type, experimental and alternative theatres have been, as in Britain and the USA, completely private institutions. They have been tolerated by the state but not financially supported by it (Kos, 1995). More precisely: project-type theatres have from time to time received some financial support for particular projects, but since they have been heavily under-financed they have had a short life. The outcome of this financial discrimination was cannibalism: project theatres have been sooner or later disintegrated and absorbed by repertory theatres.

The new law on non-profit organisations has petrified this situation, since it has nationalised all non-profit organisations (hospitals, schools, theatres etc.) and at the same time legalised private non-profit organisations which should be autonomous but also self-financed. The new law has therefore created an intransigent relationship between state regulated public organisations and private, independent organisations.

In the opinion of Slovenian social scientists, the main changes of the abovementioned law should establish transient relations between public and private 
organisations, or in our case - between public and private theatres. State regulated public repertory theatres should become more autonomous from state regulation, i.e. should be denationalised and self-managed. Actors should also be financed through public competitions for particular projects and not regularly paid as civil servants through the state budget. On the other hand, private project type theatres should have non-discriminatory status through public competition, which might substantially improve their financial situation. In this way both types of theatre should have equal access to public finances since both should be involved in a unique system of public competition. Furthermore, Slovenian experts recommend changes in state financing of all existing building but under the condition that they should be offered under the same conditions to repertory and to project theatres.

Since all the above changes might create excessive uncertainty for artists, it is recommended that government bodies should encourage the establishment of specific employment agencies which will take care for contractual employment of artists, their health and pension insurance etc.

Similar suggestions have also appeared in relation to the other public non-profit organisations like schools and hospitals. Of course, there are also differences, as one could imagine, from the previous chapters. However the common general idea is that the new law should reduce intransigent relations between public and private schools, hospitals, theatres, kindergartens etc. The new law should encourage privatisation of public organisations and on the other hand also greater financial support and professional control over private organisations.

To summarise: all suggestions are oriented towards status equalisation and regulative convergence of private and public non-profit organisations. The expected outcome of the above suggestions is the "third way", which becomes now prevailing policy orientation in EU. This orientation might be illustrated with the words of Anthony Giddens: "Third way politics, it could be suggested, advocates a new mixed economy .... The new mixed economy looks for a synergy between public and private sector utilising the dynamism of markets but with the public interest in mind" (Giddens, 1998:99-100).

\section{References}

Arronowitz, Stanley (1998), The Privatization of Public Universities, CUNY New York and UNAM Mexico City, Paper presented at IVX. World Congress of ISA, Montreal.

Ascher, K. (1989), The Politics of Privatization, London, McMillan.

Becker, Jorg, (1993), The Latin-Americanization of the East European Public Sphere after 1989, Argument, 35 5, (201), Sept.-Oct. 707-715.

Bensusan, Graciel, (1993) Entrepreneurs and Labor Legality; The Limits of Privatization, Sociological, 8, 22, May-Aug. 141-161.

Burt, Ronald, (1992), Structural Holes, Harward Univ. Press, Cambridge, Mass. 
Bovbjerg, R., Held, P.J., Pauly M., (1987), Privatization and Bidding in the Health Care Sector, Journal of Policy Analysis and Management, 6, 4, 648-666.

Casten von Otten, (1988), Responsiveness in Public Service Organizations, The Case for Public Competition and Participative management, OECD, Workshop, Amsterdam.

Cawson, Alan, (1985), Organized Interests and the State, Studies in Meso Corporativism, London, Sage.

Charles Adrian, (1985), Social Policies in Western Industrial Societies, Inst. of International Studies, Univ., of California Press, Berkeley.

Cook R. (1988), Life Begins at 40, Defence of the NHS, London, Fabian Society.

Cox, Terry, (1994), Privatization, Class and Interest Formation in Eastern Europe; in P. Brown and R. Crompton (eds.) Economic Re-Structuring and Social Exclusion, UCL Press.

Daijiro, Hida, (1993), Privatization and Secondary Private Schools, Journ, of Educational Sociology, 52, June, 72-91.

Derek, C.J.. and Takao Kato, (1993), Employee Stock Ownership Plans and Productivity in Japanese Manufacturing Firms, British Journal of Industrial Relations, 31, 3, Sept. 331-346.

Drucker, Peter, (1986), Innovation and Entrepreneurship, Harper and Row, New York.

Drucker, Peter, (1992), The Post-Capitalist Society, Butterworth Heineman, New York.

Foucault, Michel, (1980), Power and Knowledge, Harvester Press.

Friedmann, M., and Friedmann R., (1980), Free to Chice, Harmondworth, Penguin.

Giddens, Anthony, (1998), The Third Way, Polity Press, Cambridge.

Grant W., and Streeck W., (1985), Large Firms and the Representation of Bussines Unterest in the UK and West Germany Construction Industry; in Cawson A.(ed) op. cit.

Higgins J., and Rosental M., (1993), The Developement of Private Medicine in Britain and Sweden, Research in Sociology of Health Care, 10, 47-69.

Hoffman, Lily, (1998), Bringing Professions In: Medicine and Welfare State Restructuring, Paper presented at IVX World ISA Congress, Montreal.

Jorgessen, T.B., (1988), Financial Management in Public Sector; in Kooiman J. and A.E.Kjell (eds) Managing Public organizations, London, Sage.

King, D.S., (1987), The New Right: Politics, Markets, Citizen ship, London, McMillan.

Kos Albert, (1995), Privatization of Theaters; Opportunities and doubts; in Rus V.(ed) Privatization of Social Services, DZS, Ljubljana (in print).

Machonin, Pavel, (1994), Social and Political Transformations in the Czech Republic, Czech social. Review, 2, 1, Spring 71-87.

McDonald, Douglas, (1994), Public Imprisonment by Private Means, British Journ. of Criminology, 34, 1, 29-48.

McIntoch, Christopher, (1994), To Maarket, To Market, Futurist, 28, 1, Jan.-Feb. 24-28.

Mowbraj Martin, (1993), Private Agences as Public Agents, Social Service Review, 67,4, Dec., 535-546. 
Moyle, Paul, (1993), Privatization of Prisons in New South Wales and Quin sland, Howard Journal of Criminal justice, 32, 3, Aug., 231-250.

O'Looney, John, (1993), Privatization and Service Integration, Social Service Review, 67, 4, Dec., $510-534$.

Oppen, Maria, (1994), Modernization as Privatization; Conse quences for the Public Sector, Argument, 36, 2(204), March-Apr., 185-209.

Ouchi, William, (1982), Theory Z., New York, Avon.

Relman, Arnold, ( ), What Market Values are Doing to Medicine? National Forum, 73, 3, Summer, 17-21.

Rus, Veljko, (1992), Between Anticommunism and Postsocialism, teorija in Praksa, Ljubljana.

Rus, Veljko, (1994), Privatization and Justice; in Ishikawa Akihiro (ed) Market Economy and Social Justice, Tokyo, Chuo Univ.Press.

Russell, Raymond, (1985), Sharing Ownership in the Workplace, State University of New York Press, Albany.

Ryan, Mick, (1993), Evaluating and Responding to Private prisons in the United Kingdom, Inter. Journ. of the Sociology of Law, 21, 4, Dec., 319-333.

Samson, Colin, (1994), The Three Faces of Privatization, Sociology, 28, 1, Feb., 79-97.

Sasoon, Anne Showstack, (1998), Public, Private Shifting Sands: Gender and Welfare state Paper presented at XIV ISA World Congress, Montreal.

Savas, E. S., (1982), Privatizing the Public Sector, New Jersey, Chatham House.

Spark, Richard, (1994), Can prisons be Legitimate? British Journ of Criminology, 34, 1, 1428.

Whitefield, Dexter, (1993), The Welfare State, Privatization, Deregulation and Comercialization of Public Services, Pluto Press, London.

Whitely, R., Jaklich, M., Hočevar, M., (1997), Success withouth Shock Theraphy in Eastern Europe; The case of Slovenia. Paper presented at EMOT Workshop held at the WZB, Berlin, February.

Zajiček, Edvard, (1993), Economic Reform in Poland: The Dilema of Privatization or artition, International Journal of Politics, Culture and Society, 7, 1, Fall, 19-42. 